\title{
Posthumanism and educational research for sustainable futures
}

\section{Frans Kruger}

\begin{abstract}
Karen Barad's (2007) concept of intra-action and Rosi Braidotti's (2013) nomadic posthumanism are employed in this article to problematise the notion of educational research for sustainable futures. In rejecting the hierarchical dualism of Cartesian objectivism, which places the human above the non-human, I challenge the stable selfcontained subject that presuppose a dialectical relation to the other on which most educational research is premised. Instead, in drawing on the work of Barad and Braidotti, subjectivity is posited as always in the process of becoming-other through the actualisation of new relations. In light of such a subjectivity, I consider the implications for educational research for sustainable futures. Furthermore, four avenues of thought are proposed on how educational research informed by posthumanism could contribute towards sustainable futures.
\end{abstract}

\section{Introduction}

We are posthuman - biotechnologies, genetic manipulation, xenotransplanting, robotics and pharmacology. The list goes on. We live in a world that "is radically hybridised, contaminated and integrated" (Snaza, Appelbaum, Bayne, Carlson et al. 2014, p.43). According to Hayles (1999) the question of whether we live in a posthuman present is not one of reflection but one that forces us to recognise our position in the world. This recognition, however, has to a large extent not occurred in most educational research that presupposes the human as an ontological given and treats education "as a practice of humanization" (Snaza, 2013, p.38). Thus, although the notion of the human as an ontological given has been critiqued in a sustained manner for at least the last forty years, as reflected in Foucault's (1994, p.387) ascertain that "as the archaeology of our thought easily shows, man is an invention of a recent date. And one perhaps nearing its end", this critique, and the implications thereof, is not reflected in most educational research discourse. In this article I explore the call to treat the 'human' as "something other than human" (Snaza, 2013, p.50) through a consideration of Barad's 
(2003, 2007) and Braidotti's (2013) positions on posthumanism. This I do specifically in relation to how we conceptualise educational research for sustainable futures.

In bringing educational research for sustainable futures into conversation with posthumanism I frame sustainability within a vitalist brand of monism. The vitalist aspect of such a position posits matter, "including the slice of matter that is human embodiment" (Braidotti, 2013, p.35), as a self-organising and generative force, whilst monism foregrounds transversal relationality through proposing the unity of all matter. Furthermore, in drawing on Deleuze and Guattari (1994) and Bogue's $(2007,2011)$ conceptualisation of time, I work from the premise that the future is both now and to come. Since the present is both what we are and "what already we are ceasing to be" (Deleuze and Guattari, 1994, p.112), it allows for an understanding of the future as "the infinite Now. . not an instant but a becoming" (Deleuze and Guattari, 1994, p.112) and the past as a "memory of the present, a virtual double of the present moment" (Bogue, 2007, p.55). For Bogue (2011, p.77) such a conceptualisation of time positions the future as now in that it is "the becoming-revolutionary of our present and to come as the goal [movement] of our becoming". Time is thus reconsidered as an entanglement of the past, present and future. By framing sustainable futures within a vitalist monist ontology and understanding time as entangled hold important implications for educational research practices. One such implication, which forms the basis of this article, is that research concerned with sustainability and futurity cannot be based only on human concerns but should reflect the precarious position of what is conceived of as 'the human' in the posthuman present. Before proceeding it is, however, important to make clear the distinction between the posthuman present and taking up a posthumanist position.

Although the concepts of the posthuman present and posthumanism are related these concepts should not be equated (Braidotti, 2013; Wolfe, 2010). The posthuman present describes the radically hybridised world we presently inhabit. Posthumanism, on the other hand, draws on anti-humanist, ${ }^{1}$ postcolonial, anti-racism and material feminist theories in order to critique "the hierarchical dualism articulated by Cartesian objectivism" (Zembylas and Bozalek, 2014, p.39). Posthumanism does, however, not reflect a

I refer specifically to philosophical anti-humanism that problematises the notion of a universal and unitary human subject (Braidotti, 2013; Foucault,1994). 
"chronological progression or historical moment" that signals the end of humanism; rather, it is a position that seeks to problematise ontological and epistemological perspectives that makes possible conceiving of a human in essentialist terms (Pedersen, 2010, p.242). As such it reflects "the end of the humanist definition of western man" (Weaver, 2010, p.193) through foregrounding the constitutive interdependence of the human, non-human and inhuman along a culture-nature continuum (Braidotti, 2013). Crudely put, in taking up a posthumanist position one is interested in reconceptualising the relations between matter, nonhuman animals, humans, technologies and the emergence of sense in order to experiment with new (post)human subjectivities (Kruger, 2015). Such a reconceptualization problematises a humanist understanding of relationality; a relationality that always positions the human (but who is the human of such a humanism?) at the centre of all inquiry. Through always centering the human, the notion of human exceptionalism (the idea that humans are unique and should be the focus of concern) and human instrumentalism (that believe that humans have the right to control to world) are normalised and become the dominant discourse (Zembylas and Bozalek, 2014). This position is rejected in posthumanism.

I employ Barad's $(2003,2007)$ concept of intra-action and Braidotti's (2013) nomadic posthumanism as conceptual persona (Deleuze and Guattari, 1994) to problematise human exceptionalism and instrumentalism and to consider the implications thereof for educational research practices. Thus, in keeping with Deleuze's (2004, p.207) assertion that "[t]here is only action, the action of theory, the action of praxis. ..", I employ posthumanism as a "vehicle to. . . ground our powers of understanding within the shifting landscapes of the present" (Braidotti, 2013, p.75). Furthermore, in taking up the work of Barad and Braidotti I do not claim that their work represent the field of posthumanism. These authors present only two positions within a plurality of posthumanist orientations. What all of these different orientations hold in common is a shared interest to decentre the human subject through re-embedding it in the relational networks that it is composed of. In this article I consider the possibilities such a decentralisation of the human offers us to conceptualise educational research for sustainable futures within the Anthropocene. ${ }^{2}$ My argument unfolds in two parts: firstly, I briefly introduce

2 This term, coined in 2000 by Paul Crutzen and Paul Stoermer, refers to the current geological age in which the earth's ecological balance is being profoundly altered by human activity. It has to be noted that the recognition of the current epoch as the Anthropocene is still under debate. 
the concepts of intra-action and nomadic posthumanism and consider the implications of these for what it means to be human. Secondly, I consider the implications of intra-action and nomadic posthumanism for education and educational research, particularly as it pertains to how we conceive of the contribution that educational research can make towards sustainable futures.

\section{Ontological entanglement and intra-action}

Physics, specifically quantum mechanics, contribute towards dismantling an ontologically identifiable human. Based on particle-wave duality and quantum entanglement, Barad (2007) proposes that what has become known as 'the human' emerges in and as the world self-encounters. This proposition draws on the double-slit experiment that was conducted for the first time by Thomas Young in 1801. Through this experiment Young endeavoured to establish the nature of electrons (and other matter); whether they are composed of particles or waves. The double-slit experiment indicated that matter could take on both particle or wave qualities but not simultaneously. This led the physicist Niels Bohr to propose that materialisation of matter is depended on "the specific material circumstances. . . which is used to measure" (Hinton, 2013, p.178) it. For Barad this means that any "observation itself is only possible on the basis that the effect of the measurement is indeterminable. . there is no unambiguous way to differentiate between the 'object' and the 'agencies of observation"' (Barad, 2007, pp.113 and 114). The difference that does exist between an 'object' and the 'agencies of observation' is not a priori (ontological) but only emerges in the entangled becoming of these elements. Furthermore, Bohr argued that because one cannot "differentiate any subject and object outside of their entangled becoming, the very particularity of what materialises is at once an instance of the whole" (Hinton, 2013, p.179). In other words, how matter manifest is intrinsic to the process employed to measure such a manifestation. Entities then are not only constitutive of one another but are created immanently through their interaction. This is what Barad (2007) calls intra-action. It is of significance that Barad employs the term intra-action and not interaction. Whereas interaction would refer to two or more separate, pre-existing entities engaging in an encounter with one another, intra-action, in contrast, stresses the ontological inseparability of entities involved in an ongoing becomingwith one another. Thus, what we conceive of as reality is not composed of separate things-in-themselves that exists on an ontological level, but rather a 
relational phenomenon that is continuously becoming as the world encounters itself. In the words of Barad (2007, p.140): "[t]he world is a dynamic process of intra-activity". What is the implication of this position for how we conceive of the human? As there exists not separateness of 'things' from the perspective of intra-action any "spatial, ontological, and epistemological distinction that sets humans apart" (Barad, 2007, p.136) becomes impossible.

Barad's position also holds important implications for how ethics is conceived. Her argument for onto-epistemological inseparability moves ethics from the realm of pronouncing judgment on actions in response to an exteriorised other towards questions of performativity and entanglement. Ethics becomes "about responsibility and accountability for the lively relationalities of becoming,... the entangled materialisations of which we are part, including new configurations, new subjectivities, new possibilities" (Barad in Dolphijn and Van der Tuin, 2012, p.69). Thinking ontology, epistemology and ethics as inseparable, argues Barad (as cited in Dolphijn and Van der Tuin, 2012, p.69) "makes for a world that is always already an ethical matter". I return to Barad's ethics of entanglement and the concept of intra-action later as I consider these in relation to educational research for sustainable futures.

\section{Nomadic posthumanism}

Having considered Barad's (2007) onto-epistemological position, I turn my attention to Braidotti's $(2011,2013)$ nomadic posthumanism, taking cognisance of how her position relates to ethics. Whereas Barad draws on quantum mechanics to theorise her posthumanist performativity, Braidotti draws on critical, feminist and post-colonial theories to problematise the human of universal humanism. Her argument for a nomadic posthumanism unfolds along three lines: nomadic subjectivity, an immanent ethics, and a politics of affirmation. At the heart of Braidotti's (2013) thesis is a rejection of a Cartesian bifurcation of mind/body (matter), nature/culture, masculine/feminine, human/nonhuman, etc. that stands central to transcendental humanist thought. Instead she calls for a nomadic subjectivity that relinquishes the stable, self-contained subject premised on a dialectical relation to the other for a subjectivity that is always in the process of becoming-other through the actualisation of new relations. In order to achieve this conceptual shift she draws on vitalist monism. Braidotti avers that 
vitalism allows one to reject the notion that matter is lifeless but to instead view it as autopoietic and filled with life. Matter is understood as dynamic, self-organizing and generative. ${ }^{3}$ Furthermore, through drawing on a Deleuzean reading of Spinoza's substance monism allows Braidotti to posit the unity of all matter; ${ }^{4}$ a univocity of Being. The vitalist monism that informs Braidotti position is the foundation of her posthumanist nomadism; an approach that "combines non-unitary subjectivity with ethical accountability by foregrounding the ontological role played by relationality" (Braidotti, 2013, p. 93). Braidotti (2011) argues that posthumanist nomadism consists of a radical immanence in which the essential distance between the human subject, the social nexus and the environment is suspended (also see Guattari, 2000). Thus, as outward-bound the subject "is fully immersed in and immanent to a network of nonhuman (animal, vegetable, viral) relations... It is an act of unfolding of the self onto the world and the enfolding within of the world" (Braidotti, 2011, p.94). This then is a transversal subjectivity. But even as the nomadic subject is "constituted in and by multiplicity" it is still grounded and accountable because it is "based on a strong sense of collectivity, relationality and hence community building" (Braidotti, 2013, p.49). It is this collectivity and relationality that informs the ethical dimensions of Braidotti's posthumanist nomadism.

The ethical underpinning of the qualitative shift towards relationality and transversal interconnectedness "involves a creative commitment to maximising connections, and of maximising the powers that will expand the possibilities of life" (Marks, 2010, p.87-88). Nomadic posthumanism allows for an immanent and pragmatic ethics which seeks to increase joyful passions through multiplying productive relations. In keeping with vitalist monism, the

Deleuze and Guattari (1987, p. 503) allude to the notion that life can be articulated in all matter by stating that "the organism is that which life sets against itself in order to limit itself, and there is a life all more intense, all more powerful for being anorganic". Furthermore, for them the "minimal real unit" of anorganic life is the assemblage (agencement) and "not the word, the idea, the concept or the signifier" (Deleuze and Parnet, 2002, p. 51). I take note that Deleuze and Guattari's position has been criticised by Zizek and Badiou to be naïve neovitalism (Dema, 2007). I will, however, not take up this discussion here as it is not directly relevant to my argument.

$4 \quad$ For Spinoza (2006) there exists only one substance (God or Nature). Deleuze (1994) extends and inverts this position through drawing on Nietzsche's concept of eternal return to posit the interplay between difference and repetition. For Deleuze (1992, 1994) the one substance proposed by Spinoza is in fact an always-differentiating process of becoming. 
ethics proposed by Bradiotti draws extensively on Spinoza's Ethics (2006) and Deleuze's (1988a) reading thereof. Crudely put, for Spinoza the essence of a body (human and nonhuman, animate and inanimate) is its degree of power to affect and be affected. Passions, which can be joyful or sad, come from outside a body and is produced when two are more bodies interact. Joyful passions increases a body's power to act, whereas sad passions decreases a body's power to act. According to Braidotti (2010a, p.212) ethical relations constitute relations that are "conducive to joyful and empowering encounters that express one's potentia and increase the subject's capacity to enter into further relations". Potentia refers to affirmative and creative power. Importantly, this entails that an ethical posture does not take away the power of others to act but instead enables the power of the other "to expand toward unknown futures" (MacCormack, 2012, p.2).

I argue that such an ethics of affirmation can be brought into relation with the notion of sustainability through the concept of conatus. Conatus can be defined as the desire ${ }^{5}$ of bodies to preserve their essence, in other words their power to act (Deleuze, 1988a). Put differently, conatus is the "desire to actualise one's power of becoming" (Braidotti, 2010b, p.151). An affirmative posthumanist ethics is orientated towards enabling bodies to experiment with actualising their power to the fullest extent without crossing the threshold of sustainability (Braidotti, 2006). Within this context sustainability is understood as the place where interconnected bodies enter into a relationship of composition; a relationship in which neither body extends its powers to the point where the assemblage collapses or where potentia transforms into potestas (restricting, controlling power/pouvior). An ethics of sustainability is thus radically immanent and foregrounds the primacy of productive relations, creative interdependence and co-poiesis. This ethics is also postanthropocentric as it posits that all bodies (the human and nonhuman, organic and inorganic) have the power to act, to affect and be affected. It is through such an ethics that we can practice an affirmative politics that "entails the creation of sustainable alternatives geared to the construction of social horizons of hope, while at the same time doing critical theory, which implies resistance to the present" (Braidotti, 2011, p.267).

Having provided a brief overview of the posthumanist positions taken up by Barad and Braidotti and how their positions inform an ethics of sustainability,

5 Desire in the Deleuzo-Guattarian (1983) sense does not refer to a want or a lack but is an affirmative force that produces connections. 
I turn my attention to why I think as educational researchers we need to take note of the ideas presented in their work. I also suggest possible avenues for exploration and experimentation with educational research in relation to thinking about sustainable futures.

\section{The problematics of educational research}

Arguably the majority of educational research undertaken is premised on the belief that the "world is populated with individual things with their own independent sets of determinate properties" (Barad, 2007, p.19) which results in dichotomous subject/object relations. It is, however, argued by Snaza and Weaver (2014) that such bifurcation between subject and object alienates the researcher from the environment and structures hierarchical relations with the knowing human in the position of power. Such hierarchical structures promote human exceptionalism and instrumentalism. This leads to the majority of educational research being anthropocentric and speciest as it reserves the centre of the universe, and any conversation about it, to humans. Yet as Bennet (2010, p.108) argues, in a posthuman world "[to] assume a world of active subjects and passive objects begins to appear as thin descriptions at a time when the interactions between human, viral, animal, and technological bodies are becoming more and more intense". The posthumanist positions of Barad and Braidotti offer us the chance to problematise this "divide between speaking-subjects and mute objects" (Bennet, 2010, p.108) in educational research.

If one takes Barad $(2003,2007)$ and Braidotti's (2013) positions seriously that independent entities do not exist a priori and as such cannot be acted upon but instead participate in their own immanent materialisation through the relations into which they enter, we have to reconsider what we understand educational research to be, what we research, and how we conduct our research endeavours. For example, when we conduct classroom observations, work with 'objective' data during statistical analysis, or code interviews during qualitative research, we cannot treat matter (data) as a static entity that awaits signification by humans, nor can we treat matter as "an uncontested ground for scientific, feminist or Marxist theories [as m]atter is not immutable or passive" (Barad, 2003, p.821). As argued previously, this is because the observer and the observed are fundamentally entangled and ontologically inseparable (Barad, 2007). Similarly, Braidotti's (2013) brand of vital monism unfolds in her posthumanist nomadism through a relational ontology and non- 
unitary subjectivity. In positing a relational ontology humans are neither pure cause nor pure effect but part of a relational becoming-with the world. Agency (or the ability to affect and be affected) is not the sole domain of the human but is extended to include all matter.

In recognising the entanglement of time and matter and the immanence of life, educational researchers that work towards sustainable futures should take cognisance of the fact that their research practices are not only receptive of the world, but also transformative of it (Ingold, 2011). This transformative aspect of research is potentially made evident through a posthumanist position that decentres the human subject in favour of affectivity and relationality. Through such a transposition educational research moves from the realm of representation (being receptive of the world) to that of performativity (transforming the world). In following Schechner (as cited in Vannini, 2015, p.8) performativity in this instance is understood as potentiality "waiting to be actualised". Research as performance thus creates openings for experimentation with "new forms of life" (Thrift, 2008, p.14); that is, different world-becomings that decentres the human in favour of emergent and relational networks along a culture-nature continuum. Such an understanding of how posthumanism can inform educational research for sustainable futures does not necessarily reject humanistic concerns but approaches it from a post-individualistic, relational and affective perspective. Emphasising the performativity of research also potentially allows for the emergence of knowledge beyond the bounds of representation (see for example Murris, 2016). This is because such research practices would not necessarily be so much concerned with "representing an empirical reality that has taken place before the act of representation than they are in enacting multiple and diverse potentials of what knowledge can become afterwards" (Vannini, 2015, p.12). Through broadening educational research practices to not only approach the world through cognition but also affectivity and performance permit experimenting with creating different knowledge and creating knowledge differently (St Pierre, 1997). In shifting the focus of examination (and re-presentation thereof) from the actions of humans towards "how relational networks or assemblages of animate and inanimate affect and are affected" (Fox and Alldred, 2015, p.399), I consider four avenues along which educational research for sustainable futures can travel. This is done with particular reference to the posthumanist positions of Barad and Braidotti.

i. If we, as educational researchers, wish to contribute towards sustainable futures through our research practices, we have to move beyond 
universalistic notions of what constitutes the human and the associated concept of anthropocentrism. This sentiment is also echoed by Braidotti (2013), Colebrook (2014), Snaza et al. (2014) and Horsthemke (2009) who argue that any politics orientated solely towards the welfare of the human cannot address the challenges faced in the Anthropocene. These challenges include climate change, species extinction, ecological depletion, mass migrations, and increased racial intolerance to name but a few. Arguably, to remain relevant within the current global context through addressing the challenges it poses, and the processes through which such challenges arise, educational research and the educational project at large have to become posthuman and postanthropocentric. Thus, in thinking about sustainability we need to decentre the human and foreground the material-discursive relational networks with which we and our research endeavours are entangled. Doing this, I believe, will allow us to move beyond a politics of representation that seeks to model "the existence of preexisting things" (Rotas, 2014, p.76) towards a politics of performativity and co-poiesis. Such a politics is founded on a relational praxis and seek to both acknowledge the interconnectedness of the material-discursive field, as well as actively establish productive and sustainable relations. Research that draws on such a praxis treats subjectivity as transversal and geo-centred (see Braidotti, 2013, pp.8189 ) and in so doing allows for a broadened understanding of what educational research for sustainable futures could entail.

ii. A posthumanist position allows educational researchers the opportunity to focus on how humans are always already constituted in/through the in- and nonhuman. This is I believe an important onto-epistemological shift; for educational research and practices that endeavours to humanise the human (as is the telos of most historical and contemporary education projects) is always structurally bound to practices of dehumanisation (Snaza, 2013). Such dehumanisation occurs through the creation of sexualised others (e.g. women, LGBTI community), racialised others (indigenous people, post-colonial peoples) and naturalised others (animals, the environment and other nonhumans) (Braidotti, 2013). It is through becoming not-human that we start to see human differentiation more clearly and how 'humans' are constituted in and through an interconnected world. This would offer us a chance to reconfigure current humanistic identities and practices that are structurally bound to practices of dehumanisation in ways that produce new subjectivities (assemblages that are composed of human and non-human agents) and 
practices that have not yet been coded into hierarchical and dualistic systems (Braidotti, 2013). In this context, education for sustainable futures does not merely mean to conduct research that safeguard the position of the human in the future but must involve a more radical project that repositions current research practices in terms of relational onto-epistemologies and entangled time.

iii. Posthumanism offers an opportunity to experiment with transversal research practices. In thinking about research practices in terms of transversality I draw on Guattari's (2015) use of the term. For Guattari (2015, p.132) interdisciplinary research does not avoid the problematics of compartmentalisation and as such cannot "rethink human life in terms of generalised ecology - environmental, social and mental". In other words, interdisciplinary approaches to most educational research practices are still firmly rooted in a dualistic Cartesian logic and as such is incongruent with the relational ontological perspectives from which posthumanism emerges. In response, transversal research practices build on heterogeneity and heterarchy; "producing effect not of universality" (Deleuze, 1988b, p.91) and transcendence but of singularity and immanence. This means that research is positioned as a socio-political praxis based on the understanding that the emergence of the world is a continuously entangled becoming (Barad, 2007). Research practices rooted in transversality supposes that "no theory can totalise the entire field of knowledge and action. A theory multiplies and erupts in a totally different area" (Baugh, 2010, p.283). Transversal research practices thus encompasses "a transversal movement that sweeps one and the other way" (Deleuze and Guattari, 1987, p.25) through "lateral affiliations and entire system of networks" (Foucault and Deleuze, 1977, p.212).

Transversal research practices draws on an array of fields, including but not limited to critical theory, postcolonialism, feminism, queer theory, critical animal studies, media and cultural studies. For example, research on food gardens at schools offers a way to examine how climate change, structural inequality, gender, agricultural practices, mass consumerism, advanced capitalism, nutrition, curriculum and pedagogy become-with on another (see Oosterling, 2013; Rotas, 2014). Not only do the posthumanist positions of Barad and Braidotti challenge discreet disciplines (e.g. education, biology, business studies) and the place of the 'human' within these disciplines, it also provides grounding to experiment with novel methodological practices. The turn to materiality and affectivity have caused an explosion in what has been labelled post- 
qualitative, non-representational and post-representational methodologies in recent years (see for example Clough, 2008; Coleman and Ringrose, 2013; Fox and Alldred, 2015; MacLure, 2013; St Pierre, 2013, Vannini, 2015). These transversal research practices and methodologies allow for a material and affective analysis that enables connecting localised micro-politics of material-discursive practices and phenomena with macro (globalised) structures, flows and intensities through positioning research as receptive and transformative of the world.

iv. Posthumanism challenges one to let go of an ethics grounded in universal humanism when conducting research and to move towards an immanent and relational ethics. Furthermore, because "[w]e do not obtain knowledge by standing outside of the world; we know because 'we' are of the world" (Barad, 2007, p.185) it is not enough to merely acknowledge our own situatedness when conducting research. From a posthumanist perspective we are always embedded and embodied (Braidotti, 2013) in our research practices and context. As such, the knowledge produced through research is not only situated and partial but also performative as "knowing is not bounded or a closed practice but an ongoing performance of the world" (Barad, 2007, p.149).

Because we gain knowledge through unfolding with/in the world, all our research endeavours are affective and as such always already political. That is, they concern power relations (in the Spinozist sense). This means that they are also ethical. It is, however, an ethics that moves beyond recognition of the other based on a shared vulnerability towards an affirmative ethics based on interconnectedness, co-poiesis and becoming-with the other. In conducting research, we need to carefully consider whether the relations we enter into, and the relations we make possible through our research - human and nonhuman, organic and inorganic - are sustainable and extend the power of the other to act to its fullest degree.

\section{To wonder}

In Difference and Repetition, Deleuze (1994, p.139) asserts that "[s]omething in the world forces us to think". It is an interruptive encounter with the unintelligible; it is an affective encounter - "wonder, love, hatred, suffering" 
(Deleuze 1994, p.139). Thought produced through such an encounter is intensive and untimely and challenges one to grapple with the limits of understanding and with that which is unthinkable. This is I believe what posthumanism and postanthropocentrism offer us - to stand at the edge of the "failure of human knowledge to gain access to the world" (Snaza and Weaver, 2014, p.6) and to set "up conditions in which we can. . get free of ourselves and the old concepts that weigh us down" (St. Pierre, 2013, p.226). This precarious position offers us a return to 'wonder' at the becoming-world (Bogost, 2012; MacLure, 2013). As educational researchers we should not be afraid to disrupt the (humanist) logic that traps educational research within the instrumentalist confines of always asking a variant of the same question: 'What works best?' Rather, as Snaza and Weaver (2014) suggest, a posthumanist and postanthropocentric position allows us to turn this question around and ask: 'Best for what?' This is, I believe, a vital first step in starting to think about the possibilities for what educational research might become as we grapple with the problematics of sustainable futures in the Anthropocene.

\section{References}

Barad, K. 2001. Re(con)figuring space, time and matter. In Dekoven, M. (Ed.). Feminist locations: global and local, theory and practice. New Jersey and London: Rutgers University Press, pp.75-109.

Barad, K. 2003. Posthumanist performativity: toward an understanding of how matter comes to matter. Signs: Journal of Women in Culture and Society, 28(3): pp.801-831.

Barad, K. 2007. Meeting the universe halfway: quantum physics and the entanglement of matter and meaning. Durham: Duke University Press.

Baugh, B. 2010. Theory. In Parr, A. (Ed.). The Deleuze Dictionary Revised Edition. Edinburgh: Edinburgh University Press, pp.282-284.

Bennet, J. 2010. Vibrant matter: a political ecology of things. Durham: Duke University Press.

Bogost, I. 2012. Alien phenomenology, or what it's like to be a thing. Minneapolis: University of Minnesota Press. 
Bogue, R. 2007. Deleuze's way: essays in transverse ethics and aesthetics. Aldershot: Ashgate.

Bogue, R. 2011. Deleuze and Guattari and the future of politics: science fiction, protocols and the people to come. Deleuze Studies, 5: pp.77-97.

Braidotti, R. 2006. The ethics of becoming imperceptable. In Boundas, C. (Ed.). Deleuze and philosophy. Edinburgh: Edinburgh University Press, pp.133-159.

Braidotti, R. 2010a. Politics + Ecology. In Parr, A. (Ed.). The Deleuze Dictionary Revised Edition. Edinburgh: Edinburgh University Press, pp.211-213.

Braidotti, R. 2010b. Lines of Flight + Suicide. In Parr, A. (Ed.). The Deleuze Dictionary Revised Edition. Edinburgh: Edinburgh University Press, pp.151-152.

Braidotti, R. 2011. Nomadic theory: the portable Rosi Braidotti. New York: Columbia University Press.

Braidotti, R. 2013. The posthuman. Cambridge: Polity.

Clough, P. T. 2008. The affective turn: political economy, biomedia and bodies. Theory, Culture and Society, 25: pp.1-22.

Colebrook, C. 2014. The death of the posthuman: essay on extinction, Vol. 1 Ann Arbor: Open University Press.

Coleman, R. and Ringrose, J. (Eds.). 2013. Deleuze and research methodologies. Edinburgh: Edinburgh University Press.

Deleuze, G. 1988a. Spinoza: practical philosophy. (R. Hurley, Trans.). San Francisco: City Lights Books.

Deleuze, G. 1988b. Foucault. (S. Hand, Trans.). Minneapolis: University of Minnesota Press.

Deleuze, G. 1992. Expressionism in philosophy: Spinoza. (M. Joughin, Trans.). Cambridge: The MIT Press. 
Deleuze, G. 1994. Difference and repetition. (P. Patton, Trans.). New York: Columbia University Press.

Deleuze, G. 2004. Desert islands and other texts 1953-1974 (D. Laoujade, Ed.). New York: Semiotext(e).

Deleuze, G. and Guattari, F. 1983. Anti-oedipus: capitalism and schizophrenia. (R. Hurley, M. Seem and H.R. Lane Trans.). Minneapolis: University of Minnesota Press.

Deleuze, G. and Guattari, F. 1987. A thousand plateaus: capitalism and schizophrenia. (B. Massumi, Trans.). Minneapolis: University of Minnesota Press.

Deleuze, G. and Parnet, C. 2002. Dialogues. (H. Tomlinson and B. Habberjam, (Trans.). New York: Columbia University Press.

Dema, L. 2007. "Inorganic, Yet, Alive": How can Deleuze and Guattari deal with the accusation of Vitalism? Rhizomes, 15. http://www.rhizomes.net/issue15/dema.html\# ftn1 9 October 2015.

Dolphijn, R. and Van der Tuin, I. 2012. New materialism: interviews and cartographies. Ann Arbor: Open University Press.

Foucault, M. 1994. The order of things: an archaeology of the human sciences. New York: Vintage Books.

Foucault, M. and Deleuze, G. 1977. Intellectuals and power. In Bouchard, D.F. (Ed.). Language, counter-memory, practice: selected essays and interviews by Michel Foucault. Ithaca: Cornell University Press, pp.205-217.

Fox N.J. and Alldred, P. 2015. New materialist social inquiry: designs, methods and the research-assemblage. International Journal of Social Research Methodology, 18(4): pp.399-414.

Guattari, F. 2000. The three ecologies. (I. Pindar and P. Sutton, Trans.). London: The Athlone Press.

Guattari, F. 2015. Transdisciplinarity must become transversality. Theory, Culture and Society, 32(5-6): pp.131-137. 
Hayles, N.K. 1999. How we became posthuman: virtual bodies in cybernetics, literature, and informatics. Chicago: Chicago University Press.

Hinton, P. 2013. The quantum dance and the world's 'extraordinary liveliness': refiguring corporeal ethics in Karen Barad's agential realism. Somatechnics, 3(1): pp.169-189.

Horsthemke, K. 2009. Learning for the natural environment: the case against anthropocentrism. US-China Educational Review, 6(10): pp.22-30.

Ingold, T. 2011. Being alive: essays on movement, knowledge and description. Abingdon: Routledge.

Kruger, F. 2015. Experimenting with nomadic posthumanism:

conceptualising education and rural learning ecologies differently. Alternation Special Edition, 16: pp.329-345.

MacCormack, P. 2012. Posthumanist ethics: embodiment and cultural theory. Farnham: Ashgate.

MacLure, M. 2013. The Wonder of Data. Cultural Studies $<->_{-}$Critical Methodologies, 13(4): pp.228-232.

Marks, J. 2010. Ethics. In Parr, A. (Ed.). The Deleuze Dictionary Revised Edition. Edinburgh: Edinburgh University Press, pp.87-89.

Murris, K. 2016. The posthuman child: educational transformation through philosophy with picturebooks. Abingdon: Routledge.

Oosterling, H. 2013. ECO3: Doen denken. Heijningen: Jap Sam Books.

Pedersen, H. 2010. Is 'the posthuman' educable? On the convergence of educational philosophy, animal studies, and posthumanist theory. Discourse: Studies in the Cultural Politics of Education, 31(2): pp.237-250.

Rotas, N. 2014. Ecologies of praxis: teaching and learning against the obvious. In Snaza, N. and Weaver, J. (Eds.). Posthumanism and educational research. New York: Routledge, pp.75-83. 
Snaza, N. 2013 Bewildering education. Journal of Curriculum and Pedagogy, 10(1): pp.38-54.

Snaza, N. and Weaver, J. 2014. Introduction: Education and the posthumanist turn. In Snaza, N. and Weaver, J. (Eds.). Posthumanism and educational research. New York: Routledge, pp.1-14.

Snaza, N., Appelbaum, P., Bayne, S., Carlson, D., Morris, M., Rotas, N., Sandlin, J., Wallin, J. and Weaver, J. 2014. Towards a posthumanist education. Journal of Curriculum Theorizing, 30(2): pp.39-55.

Spinoza, B. 2006. Improvement of the understanding: ethics and correspondence of Benedict Spinoza. (R. Elwes Trans.). New York: Cosimo.

St. Pierre, E. A. 1997. Methodology in the fold and the irruption of transgressive data. International Journal of Qualitative Studies in Education, 10: pp.175-189.

St. Pierre, E.A. 2013. The appearance of data. Cultural Studies $<->$ Critical Methodologies, 13(4): pp.223-227.

Thrift, N. 2008. Non-representational theory: space, politics, affect. London: Routledge.

Vannini, P. 2015. Non-representational research methodologies: an Introduction. In Vannini, P. (Ed.). Non-representational methodologies: reenvisioning research. New York: Routledge, pp.1-17.

Wolfe, C. 2010. What is posthumanism? Minneapolis: University of Minnesota Press.

Weaver, J.A. 2010. ThepPosthuman condition: a complicated conversation. In Malewski, E. (Ed.). Curriculum studies handbook: the next moment. New York: Routledge, pp.190-200.

Zembylas, M. and Bozalek, V. 2014. A critical engagement with the social and political consequences of human rights: the contribution of the affective turn and posthumanism. Acta Academia, 46(4): pp.29-47. 
Frans Kruger

School of Education Studies

University of the Free State

krugerf@ufs.ac.za 